\title{
Perspective of beneficial microbes in agriculture under changing climatic scenario: A review
}

\author{
P. N. Bhattacharyya ${ }^{1 *}$, M. P. Goswami ${ }^{2}$, L. H. Bhattacharyya ${ }^{3}$ \\ 'Department of Mycology and Microbiology, Tocklai Tea Research Institute, Jorhat, Assam, India, ${ }^{2}$ Department of Biotechnology, \\ St. Anthony's College, Shillong, Meghalaya, India, ${ }^{3}$ Silviculture and Forest Management Division, Rain Forest Research Institute, \\ Jorhat 785001, Assam, India
}

Received: 08.04.2016

Accepted: 21.04 .2016

*Address for correspondence:

P. N. Bhattacharyya, Department of Mycology and Microbiology, Tocklai Tea Research Institute, Tea Research Association, Jorhat - 785008

Assam, India.

Phone: +91-9706644081,

E-mail: pranabananda01@ rediffmail.com

\begin{abstract}
Agriculture is a complex network of interactions of plants with microorganisms. There is a growing demand for ecologically compatible, environment friendly technique in agriculture that might be able to provide adequate supply of nutrients for the increasing human populations through improvement of the quality and quantity of agricultural products. Under the changing climatic scenario of global fluxes of the key biogenic greenhouse gases (carbon dioxide, methane, and nitrous oxide), and some other environmental problems, the application of beneficial microorganisms in agriculture would serve as an important alternative gateway to some of the traditional agricultural techniques. Microorganisms of agricultural importance represent key ecological strategy for integrated management practices such as nutrient management, disease, and pest management in order to reduce the use of chemicals in agriculture as well to improve cultivar performance. The present review is intended to focus on the emergence of agriculturally important microorganisms to develop an ideal agricultural system through efficient utilization of nutrients and recycling of energy and thereby to preserve the natural ecosystem resources under climate change. The progress to date in using the beneficial microflora in a variety of applications related to agriculture along with key mechanism of action is also discussed in this review.
\end{abstract}

KEY WORDS: Agriculture, agriculturally important microorganisms, climate change, ecologically compatible environment, integrated management practices

\section{INTRODUCTION}

The microbial world is the largest unexplored reservoir of biodiversity on earth (up to the last century, the nature and identity of only a tiny fraction (just $<10 \%$ ) of microscopic landscape is known) (Bhattacharyya, 2012). They constitute the largest mass of life on the planet earth. Though microorganisms constitute the smallest forms of life they are known to play vital role in every spectrum of activities within a living organism on earth. Therefore, research based on microbial ecology becomes an important frontier in present day biological science. Bacteria, fungi, algae, protozoa, actinomycetes, and the infectious agents such as viruses are the entities within the vast resources of activities of microbial diversity (Andreote et al., 2014). Microbial populations do interact and associate in various activities through different means.

Climate change is one of the major issues affecting the life on the planet earth. Climate change usually affects the photosynthesis, root activity, general morphology, and functioning of the plant specimens as well their interactions. Change in climate not only affects the potential crop yield but it may also modify the activities of pests and pathogens. If climatic change causes a gradual shift of agricultural regions, crops and their associated pests, diseases, and weeds may migrate together. Increasing atmospheric carbon dioxide $\left(\mathrm{CO}_{2}\right)$ reduces crop nitrogen content (Niklaus et al., 2007), which may retard many pests and diseases and thereby causes change in the composition of weed flora that accompanies the crops.

All plants normally exude a carbon-rich liquid that feeds the microbes (Farrar et al., 2014). Plants also exude various chemicals in response to a range of biotic and abiotic stressors, including insect attacks, and water stress. Soil bacteria sense these chemical-based messages and secrete chemicals of their own that can activate complex plant defenses in the plant (Glick, 2012). Anthropogenic activities and agriculture have stimulated 
the production of greenhouse gases (Hunter, 2008). Soil microorganisms contribute significantly to the consumption of greenhouse gases (Bardgett et al., 2008), including $\mathrm{CO}_{2}$, methane $\left(\mathrm{CH}_{4}\right)$, nitrous oxide, and nitric oxide (NO). As concentration of these gases continue to raise, soil microbes may exhibit feedback responses that may accelerate or slow down global warming, but the extent of these effects are unknown. Understanding the role of soil microbes both as contributors and reactive components of climate change can help us to determine whether they can be used to curb emissions or if they will push us even faster toward climatic disaster. The present research aims in exploring the beneficial aspects of microbes in nutrient management and crop protection with particular reference to changing climate scenario, the research on which is important to combat the agriculture against drought and several stress situations related with climate change.

\section{Agriculturally Important Microflora (AIM)}

AIMs have diverse applications in agriculture, horticulture, and forestry (Arora et al., 2005). AIMs are often designated as a large group of frequently unknown or ill-defined microorganisms (Higa and Parr, 1994) that interact favorably in soils and with plants to render beneficial effects which are sometimes difficult to predict. Table 1 shows the beneficial aspects of AIMs on certain plant species. Azotobacter chroococcum, Azospirillum basilensis, Bacillus weihenstephanensis, Bradyrhizobium sp., Paenibacillus sp., Pseudomonas corrugate, Rhizobium sp., etc. have established their efficiency in plant growth promotion. The microorganisms also play a key role in crop protection through enhancing the disease resistance capacity of plants against pathogens, exhibiting antagonistic activities or acting as biotic elicitors against different biotic and environmental factors. The term "Effective Microorganism" is usually denoted to a group of cultures of known, beneficial microorganisms that are being used effectively as microbial inoculants (Higa and Wididana, 1991) that can be applied to increase the native microbial diversity of soils and rhizosphere of the growing plants. Microorganisms are valuable in managing the invertebrates and vertebrate pests, plant diseases, weeds, and other pests that usually damage the agricultural crops and forestry. Fungi can colonize upper parts of the plants and provide it benefits to drought as well heat tolerance, resistance to insects, and various plant diseases (Singh et al., 2011). Viruses are even helpful at extreme situations (even at temperatures up to $115^{\circ} \mathrm{F}$ ) inYellowstone National Park, where it colonize the plant roots to build a symbiotic association (Roossinck, 2011). Thus, the uniqueness of microorganisms and their unpredictable nature and biosynthetic capabilities make them quite adaptable in specific environmental and cultural conditions to solve various problems related with crop improvement and disease suppression.

Since microorganisms are useful in eliminating problems associated with the use of chemical fertilizers and pesticides, they are widely been applied in natural farming and organic agriculture (Russo et al., 2012). Microbial biotechnology and its application in sustainable development of agriculture and environmental health are getting better attention. The purpose of the review is to further prioritize the importance of microbial-based technology in agricultural sector for the greater benefit of the scientific community as well as stakeholders.

\section{Ideal Agricultural System and Role of Beneficial Microbes}

Agricultural technologies that ensured green revolution in the middle of $20^{\text {th }}$ century has recently earned high

Table 1: AIMs and their contributions in target plant species

\begin{tabular}{|c|c|c|c|}
\hline AIMs & Target plant & Beneficial effect & References \\
\hline $\begin{array}{l}\text { Azospirillum sp., } \\
\text { Azotobacter sp. }\end{array}$ & $\begin{array}{l}\text { Cynara } \\
\text { scolymus }\end{array}$ & $\begin{array}{l}\text { Known to increase radical and shoot length, shoot weight. } \\
\text { Have significant affect in germination }\end{array}$ & Jahanian et al., (2012) \\
\hline $\begin{array}{l}\text { Pseudomonas sp. } \\
\text { strain PS } 1\end{array}$ & $\begin{array}{l}\text { Vigna } \\
\text { radiata }\end{array}$ & $\begin{array}{l}\text { It helps to increase plant dry weight, root nodule, total } \\
\text { chlorophyll content, seed yield and seed protein }\end{array}$ & $\begin{array}{l}\text { Ahemad and Khan, 2012a; } \\
\text { Ahemad and Khan, 2011a }\end{array}$ \\
\hline $\begin{array}{l}\text { Bradyrhizobium sp. } \\
\text { strain M RM } 6\end{array}$ & $\begin{array}{l}\text { Vigna } \\
\text { radiata }\end{array}$ & $\begin{array}{l}\text { The bacterium can increase the growth parameters at tested } \\
\text { concentrations of various herbicides }\end{array}$ & $\begin{array}{l}\text { Ahemad and Khan, 2012b; } \\
\text { Ahemad and Khan, 2011b }\end{array}$ \\
\hline $\begin{array}{l}\text { Pseudomonas sp. } \\
\text { strain A3R3 }\end{array}$ & $\begin{array}{l}\text { Brassica } \\
\text { juncea }\end{array}$ & The bacterium has proved its ability in biomass increase & Ma et al. (2011) \\
\hline $\begin{array}{l}\text { Rhizobium } \\
\text { strain MRP1 }\end{array}$ & $\begin{array}{l}\text { Pisum } \\
\text { sativum }\end{array}$ & $\begin{array}{l}\text { This bacterium is known to increase the symbiotic } \\
\text { properties of plants like nodulation and leghaemoglobin } \\
\text { content, enhancement of nitrogen and phosphorous uptake, } \\
\text { seed yield and seed protein }\end{array}$ & $\begin{array}{l}\text { Ahemad and Khan, } 2011 \text { a; } \\
\text { Ahemad and Khan, 2010; } \\
\text { Ahemad and Khan, } 2009\end{array}$ \\
\hline $\begin{array}{l}\text { Bacillus } \\
\text { weihenstephanensis } \\
\text { strain SM3 }\end{array}$ & $\begin{array}{l}\text { Helianthus } \\
\text { annuus }\end{array}$ & $\begin{array}{l}\text { The bacterium can increase plant biomass and accumulation } \\
\text { of trace elements like } \mathrm{Cu}, \mathrm{Ni} \text { and } \mathrm{Zn} \text { in the roots and shoot } \\
\text { systems along with their mobilizing potential }\end{array}$ & Rajkumar et al. (2008) \\
\hline $\begin{array}{l}\text { Bacillus sp., } \\
\text { Paenibacillus sp. }\end{array}$ & $\begin{array}{l}\text { Oryzae } \\
\text { sativa }\end{array}$ & The bacterium can promote the root and shoot growth & Beneduzi et al. (2008) \\
\hline
\end{tabular}


ecological cost (Scherr and McNeely, 2008) and thereby contribute global pollution, unfavorable climate change, and loss of biodiversity. An ideal agricultural system is economically and spiritually beneficial to both producers and consumers including human beings. It should actively preserve and protect the environment, self-contained and regenerative, and produce enough food for an increased world population. An ideal agricultural system needs proper care on certain issues such as nutrient management, efficient utilization and recycling of energy, and preservation of natural resources and environment.

\section{Nutrient Management}

Nutrient management is the science related with optimal utilization of soil, weather, hydraulic factors, and essential NPK inputs (Miao et al., 2011) with diverse cultural and physical conservation strategies that directly or indirectly helps in optimization of exploitation in nutrient use efficiency improving plant quality as well as soil health and environment. Plants generally absorb nutrients directly from soil through the rhizosphere and from the atmosphere through phyllosphere (Turner et al., 2013). Compounds released through different parts of the plant root system may create a special environment in the rhizosphere. These compounds are collectively termed as root exudates that generally belong to three main classes such as lowmolecular weight, high-molecular weight, and volatile organic compounds (VOCs) (Ortiz-Castro et al., 2009). Low-molecular weight compounds represent the main portion of root exudates and consist of sugars, amino acids, organic acids, phenolics, vitamins, and various secondary metabolites. High-molecular weight compounds consist of mucilage and proteins, whereas $\mathrm{CO}_{2}$, certain secondary metabolites, alcohols, and aldehydes constitute volatiles. Several factors such as temperature, light, age, and soil type can affect the nature and timing of root exudation (Badri andVivanco, 2009). In plants grown under low phosphate availability or in the presence of toxic concentration of aluminum, the exudation of organic acids such as oxalic acid, malic acid, and citric acid is particularly increased. These compounds might act as signals for microbial attraction or be used as carbon sources for microbial nutrition (Nihorimbere et al., 2011).

Traditional farming practices have reached their limits of effectiveness in increasing agricultural productivity. In $21^{\text {st }}$ century, peoples are demanding for more and quality food. These pressures are multiplied by shrinking farmland, rising labor costs, and shortage of farm workers. To improve the sustainability of existing agricultural system and to produce more and better quality of our agricultural products, beneficial microbes are used. Microbes present in soil and atmosphere plays a vital role in the nutrient management (Adhya et al., 2015). Soil microbes, particularly bacteria and fungi, are found as essential in decomposing the soil organic matter and recycling of organic residues (Neill and Gignoux, 2006). Potentiality of microbials such as Aspergillus niger, A. chroococcum, Azospirillum brasilense, Bacillus subtilis, Pseudomonas corrugata, Rhizobium sp., and Streptomyces nojiriensis in enhanced growth of plants along with pest and disease suppression are reported (Bhattacharyya and Jha, 2012; Phukan et al., 2012). Antagonistic actinomycetes, native to soil habitat are also found as effective in controlling certain plant pathogens (Sarmah et al., 2005) through proper nutrient supply. In rhizosphere, bacteria are comparatively competing more for nutrients and ecological space (Bhattacharyya et al., 2015), as a consequence of which they have developed various offensive tools for intra and interspecies competition, such as antibiotic substances, bacteriolytic enzymes, and bacteriocins (Sood et al., 2007).

Beneficial microbials are also known for their ability to make associations with plant roots that ultimately helps in supplying important nutrients such as nitrogen, phosphorus, and potassium. Arbuscular mycorrhizal fungi (AMF) are a group of helpful microbiota known for their symbiotic associations with the roots of higher plants (Salvioli et al., 2016). They are normally obligate or sometimes saprophytic in nature and hence always require a living host for their survival. Through symbiotic associations with plant roots, AMF helps in the absorption of minerals such as $\mathrm{P}$, water, and other important macro and essential micro elements and make them available for the growing plants. Symbion-AMF (endomycorrhizae) may be applied in crops such as cereals, pulses, oil seeds, and fruit crops to increase their nutritional requirement (Jeffries and Barea, 2001). Algal genera such as Anabaena, Aphanocapra, Chrococcus, Oscillatoria, and Phormidium are known for their ability to fix atmospheric nitrogen, especially in the paddy fields (Hasan, 2013; Shridhar, 2012). There are also certain blue-green algae that possess the ability for symbiotic associations with some other beneficial microorganisms such as fungi, mosses, liverworts, and aquatic ferns (Azolla) and thereby contribute significantly in the nutrient management process.

\section{Efficient Utilization and Recycling of Energy}

Photosynthesis is the vital process in plant life. Photosynthesis depends on the plant's ability to utilize solar 
energy in fixing atmospheric $\mathrm{CO}_{2}$ into carbohydrate. The energy is further utilized for the biosynthesis of essential components such as amino acids and proteins. However, the fixation of $\mathrm{CO}_{2}$ by green plants in photosynthesis is sometimes getting extremely low mainly because of the low utilization rate of solar energy by green plants. Therefore, an integrated and efficient energy utilization process is need to be explored to increase the level of solar energy utilization efficiency by green plants, so that maximum amount of atmospheric $\mathrm{CO}_{2}$ can be converted into nutrients. Exploration of diverse ways of recycling organic energy usually accumulated in plants and animal residues through direct utilization of organic molecules by plants is an area need to focus in an ideal agricultural system. Microorganisms are essential tool in majority of the soil ecosystem services (Aislabie and Deslippe, 2013) such as efficient utilization of solar energy and recycling of organic molecules. They play crucial role in the biogeochemical cycling of soil nutrients (Bhattacharyya and Jha, 2012). This ensures the turnover and supply of nutrients that are essential for crop growth through the inter-conversion of different forms of nitrogen, sulfur, and phosphorous molecules, interlinked with the carbon cycle. Microorganisms are responsible for the maintenance of soil structures and sustainability of soil quality for efficient plant growth. Microbial activity in soil is also essential to execute carbon losses to the atmosphere through respiration and methanogenesis, micro-remediation, through degradation of organic pollutions and immobilization of heavy metals, and thereby improving soil quality (Prosser, 2007). However, it is not an easy task to develop an ideal agricultural system until and unless the efficiency of utilizing the solar energy by green plants is increased and the energy contained in existing organic molecules such as amino acids, peptides, and carbohydrates is utilized by the plant. New technologies that can improve the economic viability of farming systems with little or no use of chemical fertilizers/pesticides are need to develop for better agricultural practices.

\section{Preservation of Natural Resources and Environment}

Animal produced organic wastes, residues of agricultural and marine processing industries, and municipal wastes such as sewage and garbage have become major sources of environmental pollution in both developed and developing countries. The production of $\mathrm{CH}_{4}$ from paddy fields and ruminant animals and emission of $\mathrm{CO}_{2}$ from the burning of fossil fuels, land clearing, and organic matter decomposition are some of the serious problems directly related with global warming (Davidson and Janssens, 2006). Chemical-based conventional systems of agricultural practices have also contributed significantly in the degradation of environment and destruction of natural resources. Recycling of diverse pollutants/organic residues through proper utilization is an area need to develop for an ideal agricultural system. Application of suitable microbial resources may hold a suitable promise in conservation of natural resources and environment (Verstraete et al., 2007). Many microbes can grow in large communities called biofilms (Davey and O'toole, 2000), where the microbial cells work together and produce a sticky matrix that holds the cells together and provides protection from environmental threats. A bacterium called Bacillus, commonly found in soil, protects itself by forming a water repellent coat (Nicholson et al., 2000). The process is due to a protein called BsIA produced by the bacterium. The protein spontaneously assembles to form a water repellent coat, protecting the Bacillus cells underneath. As B. subtilis is currently examined to assess its suitability to use as a widespread bio-fertilizer, the technology of biofilm formation might aid a potential incorporation to develop an ecologically sound method of crop protection.

\section{Potential Role Played by Microorganisms}

\section{Production of plant growth regulators}

Plant growth regulators are synthetic substances similar to natural plant hormones. They can regulate the growth of plants and therefore important in agriculture. Plant growth regulators are not hazardous to human health if they are used in accordance with proper scientific practices and dose. Microorganisms inhabiting rhizosphere of growing plants are likely to synthesize and release auxin, a plant growth regulator, as secondary metabolites (Kapoor et al., 2012). Plant morphogenic effects are the results of existence of different ratios of plant hormones usually produced by roots as well as rhizosphere bacteria. Diverse soil microorganisms including bacteria, fungi, and algae are responsible in producing physiologically active compounds such as various plants growth regulators which may exert physiological effects on plant growth and development (Ahemad and Kibret, 2014). Plant growth promoting rhizobacteria (PGPR) can alter root architecture and promote plant growth with the production of phytohormones such as indole acetic acid (IAA), gibberellic acid, and cytokinins (Kloepper et al., 2007) and production of important metabolites such as siderophores, $\mathrm{HCN}$, and antibiotics. IAA is one of the most important physiologically active auxins. Several PGPRs as well as some pathogenic, symbiotic and freeliving rhizobacterial species are known to produce IAA and gibberllic acid in the rhizosphere that have immense potentiality in enhancing the root surface area and 
number of root tips in plants (Han et al., 2005). Figure 1 represents the beneficial aspects of IAA secreted by rhizobacteria. Reports are also available explaining the potentiality of fungi in plant growth promotion (Rahi et al., 2009; Murali et al., 2012). Beneficial fungi are associated with the destruction of fungal pathogens, production of antibiotics, elicitation of defense responses, etc. In addition, many beneficial fungi are able to parasitize spores, sclerotia or hyphae of pathogenic fungi and thereby contribute in biocontrol (Mejia et al., 2008). Production of a large number of degradative enzymes, including chitinases, proteases, and glucanases, is involved in this biocontrol process. Many Trichoderma strains are reported to colonize in association with diverse plant roots and thereby significantly assist in increasing plant growth and development (Saba et al., 2012). In Arabidopsis, normal auxin perception is a prerequisite for growth enhancement when inoculated with Trichoderma virens (Contreras-Cornejo et al., 2009). Root colonization by Trichoderma sp. is frequently associated with the induction of both local and systemic resistance that depends on the production of an elicitor protein called Sm1 (small protein 1) (Djonovic et al., 2006). Sml lacks toxic activity to plants and microbes. Native and purified form of $\mathrm{Sm} 1$ can trigger the production of reactive oxygen species (ROS) in rice and cotton seedlings and thereby induces the expression of defense-related genes both locally and systemically. The beneficial effects of fungi on plant growth and development might be associated with mechanisms such as mycoparasitism (Jeffries, 1995) followed by direct growth toward it, recognization of host pathogen and its damage.

\section{Phosphorous solubilization}

Plants acquire phosphorus from soil as phosphate anion. It is the least mobile element in plant in contrary to other macronutrients. Phosphorus solubilizing microorganisms (PSMs) play an essential role in phosphorus nutrition by enhancing its availability to plants through release of organic and inorganic soil phosphorus pools by solubilization and mineralization (Walpola and MinHo, 2012; Sharma et al., 2013). Lowering of soil pH by microbial production of organic acids and mineralization of organic phosphorus by acid phosphatase are the essential mechanisms usually involved during phosphorous solubilization. A general module of functioning of PSMs in agriculture is represented in Figure 2. Maximum efficiency of phosphorus solubilizing bacteria (PSB) is achieved when it is co-inoculated with other beneficial bacteria or mycorrhizal fungi (Mohammadi, 2012). Bacteria are observed as more effective than fungi in phosphorous solubilization (Sharma et al., 2013). Beneficial microflora such as Penicillium bilaii helps in unlocking phosphate from native soil. The fungus is believed to produce an organic acid that dissolves the phosphate in soil so that plant roots can easily utilize it. Among the soil bacterial communities, ectorhizospheric strains of Pseudomonas and Bacilli, Rhizobium, Enterobacter, and endo-symbiotic rhizobia are recorded as effective strains of phosphate solubilizers (Khan et al., 2009). A recent estimate suggests that PSB constitute about $1-50 \%$ in normal soil while phosphate solubilizing fungi have only 0.1-0.5\% populations (Panhwar et al., 2011). While fungal genera such as Aspergillus and Penicillium are the most powerful phosphorus solubilizers (Saxena et al., 2013). Species such as Bacillus megaterium, Bacillus circulans, Bacillus subtilis, Bacillus polymyxa, Bacillus sircalmous, and Pseudomonas striata are also potent strains of phosphate solubilizers (Rodriguez and Fraga, 1999). A nematofungus, Arthrobotrys oligospora have the ability to solubilize the phosphate rocks. The diversity and dominance of beneficial microbial populations such as

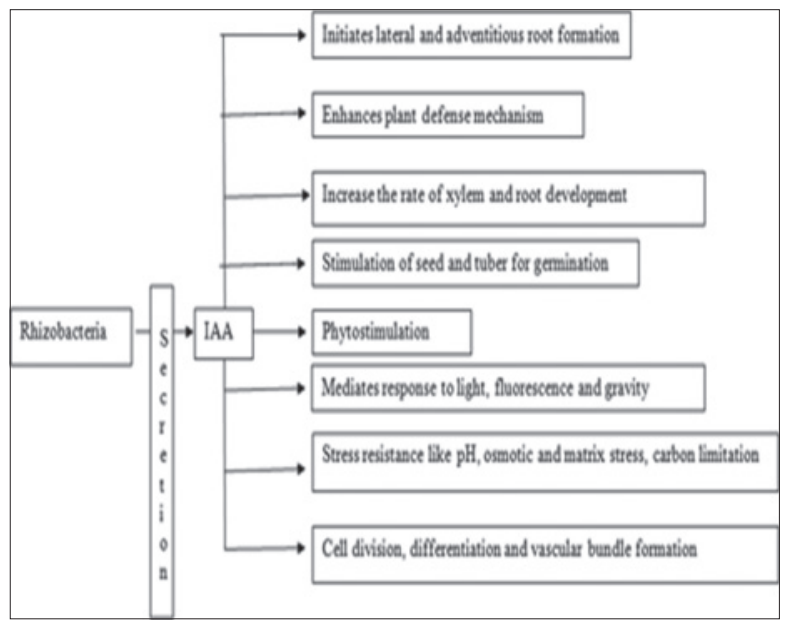

Figure 1: Significant role of rhizobacteria-induced indole acetic acid

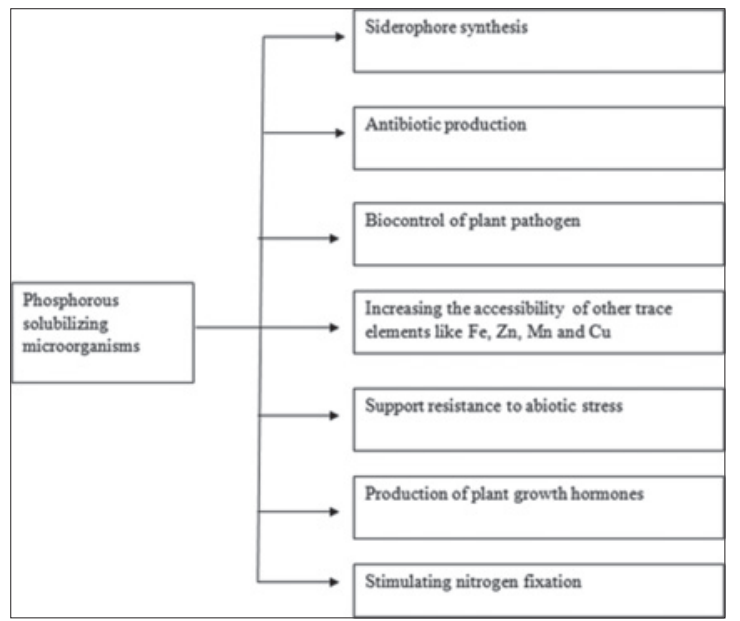

Figure 2: Significant contributions of phosphorus solubilizing microorganisms in agriculture 
phosphate solubilizers depend on biotic and abiotic factors prevailing in a particular ecological niche.

\section{Potash mobilization}

Potassium (K) is one of the vital components of plant nutrition packages that perform a multitude of important biological functions to maintain quality plant growth. $\mathrm{K}$ is usually abundant in soils. Total $\mathrm{K}$ content in top soil ranges from 3000 to $1,00,000 \mathrm{~kg} / \mathrm{ha}$ (Bertsch and Thomas, 1985). Water-soluble (solution K), exchangeable, nonexchangeable, and structural or mineral are the four different forms of K in soil (Sparks and Huang, 1985). Figure 3 represents the interrelations among different forms of soil K (Sparks and Huang, 1985). The extent of $\mathrm{K}$ released by soils, however, depends on change in soil parameters such as $\mathrm{pH}$, moisture content, texture, oxygen level, soil tilling and temperature, topographical, and biogeochemical characters. (Basak and Biswas, 2009). Certain microbes have the ability for $\mathrm{K}$ mobilization. For instances, one of the possible means of utilizing feldspar, waste mica, rock phosphate, or muriate of potash is by mobilizing their $\mathrm{K}$ through beneficial microbial activity where unavailable $\mathrm{K}$ is converted into plant available form through dissolution effects of organic acids (Sessitsch et al., 2013) secreted during $\mathrm{K}$ transformation and nutrient cycling. Microorganisms such as Acidithiobacillus ferrooxidans, Arthrobacter sp., Azotobacter sp., Bacillus mucilaginosus, Bacillus edaphicus, Frateuria sp., Klebsiella sp., Paenibacillus sp., Pseudomonas sp., Rhizobium sp., etc. (Sheng, 2005; Lian et al., 2008; Liu et al., 2012) are known for their potential role in mobilizing insoluble native K-source in soil into plant available nutrient pool. KMB would serve as an asset in this regard as an effective biofertilizer which if integrated with reduced level of $\mathrm{K}$ fertilizers would in turn provide high crop yield with low cost and

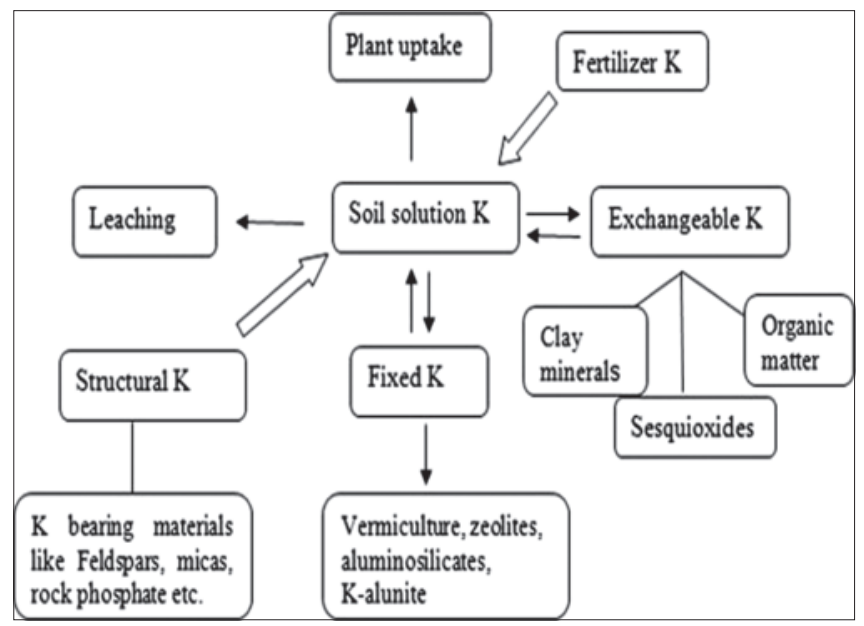

Figure 3: Interrelations among different forms of soil K (adapted from Sparks and Huang, 1985) support eco-friendly crop production. The knowledge on biodissolution by potash mobilizers is also essential to develop technologies such as biomineralization, bioremediation, and biohydrometallurgy.

\section{Microorganisms as biofertilizer and biopesticide}

Microbial biofertilizers and biopesticides are the best modern tools in agriculture (Bhardwaj et al., 2014). Microbial biofertilizers are the substances that contain live microorganisms which, when applied on the seed, plant surface or soil, colonize the rhizosphere, and promote plant growth through increased supply of primary nutrients for the host (Bhattacharyya and Jha, 2012; Vessey, 2003). While microbial biopesticides are those microorganisms that promote plant growth by controlling phytopathogenic agents through a wide variety of mechanisms such as production of antibiotics, siderophores, $\mathrm{HCN}$, production of hydrolytic enzymes, acquired and induced systemic resistance (Somers et al., 2004; Chandler et al., 2008). Native microorganisms are usually exploited to develop biofertilizer and biopesticide to assist plant growth promotion as well pest and disease control. Rhizobium is a bacterium that can be used in agriculture as an effective biofertilizer. Rhizobia are known for their ability to establish symbiotic interactions (Shridhar, 2012; Wang and Martinez-Romero, 2012) with leguminous plants by the formation and colonization of root nodules, where the bacteria can fix nitrogen to ammonia and make it available for the plant. Addition of efficient Rhizobium strains in soil is in practice in many crops, since they can improve soil fertility and help in plant growth by improving nutrient availability. Rhizobium biofertilizer in legumes are reported for their ability to replace chemical nitrogen up to 30 $35 \%$ when they are applied along with the chemical fertilizers in field (Mia et al., 2010). Likewise, Acetobacter, Allorhizobium, Aspergillus, Azorhizobium, Azospirillum, Azotobacter, Bacillus, Bradyrhizobium, Mesorhizobium, Penicillium, Pseudomonas, Rhizobium, etc., have established their efficacy as potent plant growth promoters (Vessey, 2003). However, scientific preparation and application of microbial formulation is important while developing the agriculture in a sustainable way.

\section{Production of VOCs}

VOCs generally represent an orchestrated response to a wide range of stimuli in plants and microbes (Ortiz-Castro et al., 2009). VOCs have high vapor pressures under normal conditions to significantly vaporize and enter in the atmosphere. Low molecular weight compounds $(<300 \mathrm{~g} / \mathrm{mol})$, such as alcohols, aldehydes, ketones, and hydrocarbons. falls under this category. Choudhary et al. 
(2008) have observed that VOCs are actively produced and used as a sophisticated language by plants to pursue communication with other groups of organisms such as microbials. Steeghs et al. (2004) explored the Arabidopsis rhizosphere for VOC emission and observed its induction due to biotic stresses. Several volatiles such as alcohols, aldehydes, acids, ketones, esters, and terpenes are produced constitutively or induced specifically as a result of different positive or negative interactions with microbes. Choong et al. (2004) recorded the emission of VOCs such as 2, 3-butanediol and acetoin by PGPR strains such as B. subtilis, Bacillus amyloliquefaciens, and Enterobacter cloacae that significantly promoted the growth of Arabidopsis thaliana, suggesting that synthesis of bioactive VOCs is a strain-specific phenomenon. It has been established that the VOCs emitted by the rhizobacterial strains can act as signaling molecule to mediate plant--microbe interactions to trigger the plant response toward beneficial microflora colonization. Low-molecular weight plant volatiles such as terpenes, jasmonates, and green leaf components act as signal molecules for living organisms at different trophic levels (Farmer, 2001). However, to acquire a clear appreciation on the mechanisms of VOCs in signaling plants to register themselves against pathogens, efficient knowledge on nature, and accumulation of volatile components in plant-rhizobacteria system need to be explored.

\section{Microbes as Biotic Elicitors}

Elicitors are molecules usually involved in plant defense mechanism (Thakur and Sohal, 2013). Most of the elicitors are derived from microorganisms irrespective of their nature and type. Exogenous application of defense signaling molecules such as salicylic acid, methyl jasmonate, and NO induces the accumulation of a wide range of secondary metabolites such as indole glucosinolates, phytoalexins, and alkamides that have immerse potentiality to communicate with beneficial microbial populations (Ortiz-Castro et al., 2009). Signal perception is the first committed step toward the biotic elicitor signal transduction pathway in plants (Yang et al., 1997). For instances, jasmonic acid and its methyl ester are the signal transducers in a wide range of plant cell cultures that might accumulate rapidly when the suspension cultures of Rauvolfia canescens L. and Eschscholtzia californica Cham. are treated with a yeast elicitor (Roberts and Shuler, 1997). The purification and characterization of specific elicitor-binding protein is essential for detailed understanding of the molecular basis of signal exchange between the hosts and microbial pathogens that eventually leads to activation of host defenses.

\section{Microbes in Bioremediation}

Bioremediation is the use of organisms to metabolize pollutants. Microorganisms like bacteria, archaea and fungi are known as the prime bioremediators. Bioremediation relies on living organisms to consume and break down the complex compounds, turning it into harmless, natural substances (Kumar et al., 2011), so that it can be disposed at a faster rate and thereby reduce environmental pollution. Bioremediators are the organisms used in bioremediation process.

Mycoremediation (Rhodes, 2014) is the process where fungi are used to decontaminate a particular area. Fungal mycelium is known to secrete extracellular enzymes and acids that have the ability to break down the plant fibers such as lignin and cellulose. Wood degrading fungi are particularly effective in breakdown of aromatic pollutants such as toxic components of petroleum, as well as chlorinated compounds (Rhodes, 2014). Mycofiltration is a process to remediate/metabolize pollutants using fungal mycelia to filter toxic wastes and microorganisms of water bodies as well soil. Different oxidation-reduction reactions are usually accompanied by bioremediators to oxidize the harmful pollutants. However, determining the right microbial species to target a specific pollutant is need to be explored to strengthen the concept of bioremediation using microbes.

\section{Microbial Responses in Stress Agriculture}

Drought is a global threat to agricultural productivity (Gornall et al., 2010). During drought, plants modulate a series of physiological responses such as the stomatal closure due to an increase of abcisic acid content, the accumulation of compatible solutes, the increased expression of aquaporins and vacuolar $\mathrm{H}$-pyrophosphatases for maintaining the cell turgidity through osmotic adjustments. Ethylene levels also reach at a higher concentration that extensively blocks plant growth (Burg, 1973) and thereby increase root to shoot ratio. An extensively larger root system is, thus, stimulated to increase the water adsorption area. Accumulations of ROS also occur that dramatically deteriorates the cell integrity and functionality and survival of the plant (Gill and Tuteja, 2010).

Rhizosphere and endosphere are the two important regions where optimum colonization of microbials reported (Berg et al., 2014). Mycorrhizal fungi and PGP bacteria are capable of modulating the physiological responses (Vacheron et al., 2013) and thereby helps in increasing plant tolerance to survive under adverse environmental 
conditions. In vitro as well as pot experiments confirmed the potentiality of rhizosphere and endosphere bacteria in improving the plant growth and tolerance during stress. The plant growth of microbial inoculated plants increased up to $40 \%$ suggesting the potentiality of PGP microbes in agriculture (Perez-Montano et al., 2014). The role of plant-associated microbiomes in plant adaptation toward drought is, thus, emerging. Microbiome composition at a particular environmental condition may vary significantly (Marasco et al., 2012) as it strictly depends on the taxonomic variability of the associated plant species.

\section{Microbial Antagonism}

Beneficial microorganisms can suppress the growth of phytopathogens in a variety of ways such as competing for nutrients and space, limiting the supply of available nutrients to pathogens (Marasco et al., 2012). The microflora of disease-suppressive soils is usually dominated by antagonistic microorganisms that have the ability to produce diverse array of antibiotics (Mohseni et al., 2013). Aspergillus, Penicillium, Trichoderma, and antagonistic actinomycetes are known as potent hub to produce diverse antibiotics (Zivkovic et al., 2010) of varying mode of action. Many strains of Trichoderma are strong opportunistic invaders (Rahul et al., 2014). Antibiotics produced by antagonistic microbials have biostatic and biocidal effects on soil-borne plant pathogens.

\section{Microbial Interactions and Biocontrol in the Rhizosphere}

Biological control is the use of beneficial natural enemies to reduce the numbers of pathogenic organisms. The natural enemies include antagonistic and competitor microorganisms that are known to kill or inhibit the pathogenic microbes. Biological control agents are less toxic, more flexible and cost-effective than chemical pesticides (Bale et al., 2008). Bacteria are usually applied in the seeds and the roots of many plants for controlling various microbial diseases. For instances, nonpathogenic strains of Streptomyces sp. are known to control scab of potato (Solanum tuberosum L.) caused by Streptomyces scabies (Neeno-Eckwall and Schottel, 1999). The antagonistic activity of Streptomyces is likely to be associated with the production of extracellular hydrolytic enzymes and secondary antifungal metabolites. Similarly, an antagonistic bacterium, Pseudomonas fluorescens worked against the soft rot potato pathogen, Erwinia carotovora subsp. atroseptica (Cronin et al., 1997). Production of 2, 4-diacetylphloroglucinol and siderophore might be involved in the antagonism. Pseudomonas species are also known to control crown gall disease in dicotyledon (Tolba and Soliman, 2013). The most widely used nonpathogenic Agrobacterium strain K84 produces a highly specific antibiotic agrocin 84 (Penyalver and Lopez, 1999) that is encoded by plasmid pAgK84. Inundative inoculation of Agrobacterium strain K84 to roots by dipping in cell suspensions prior to exposure to the pathogen effectively controls those strains of pathogen susceptible to agrocin 84. Antibiotics such as agrocin 434 or ALS 84 might be involved here (McClure et al., 1998). The filamentous fungi, Trichoderma, and Gliocladium are reported for their efficiency against different phytopathogens such as Alternaria, Botrytis, Colletotrichum, Diaporthe, Fusarium, Monilinia, Phytophthora, Phythium, Rhizoctonia, Sclerotinia, and Verticillium (Begum et al., 2008; Hajieghrari et al., 2008; Imtiaj and Lee, 2008) restricting the growth and possible spore development. Bacillus produce several antifungal compounds with significant inhibitory activity against Ceratocystis ulmi (Gregory et al., 1986), Colletotrichum, musae (Mahadtanapuk et al., 2007; Alvindia and Natsuaki, 2009) and Colletotrichum gloeosporioides (Demoz and Korsten, 2006), Euthypa lata (Ferreira et al., 1991), Fusarium moniliforme (Agarry et al., 2005). Further, extensive molecular and ecological studies are need to be identified to understand the biological control of microbial inoculants.

\section{Quorum Sensing (QS)}

QS refers to the regulation of gene expression in response to fluctuations in cell population density (Miller and Bassler, 2001). Bacteria are known to produce and release chemical signal molecules called autoinducer (AI) molecules responsible for cell to cell communications. The detection of a minimal threshold stimulatory concentration of an auto inducer leads to an alteration in gene expression. Gram-positive and Gram-negative bacteria use QS communication circuits (Rutherford and Bassler, 2012) to regulate a diverse array of physiological activities within a living cell. The processes include symbiosis, virulence, competence, conjugation, antibiotic production, motility, sporulation, and biofilm formation. In general, Gram-negative bacteria use acylated homoserine lactones as auto inducers and Gram-positive bacteria use processed oligopeptides to communicate (Miller and Bassler, 2001). Commonly reported autoinducer signals are $\mathrm{N}$-acyl homoserine lactones (von Bodman et al., 2003), although half a dozen of other molecules, including diketopiperazines in several Gram-negative bacteria (Holden et al., 1999), furanosyl borate diester in Vibrio harveyi (Chen et al., 2002) and c-butyrolactone in Streptomyces (Yamada and Nihira, 1998) have also been implicated in density-dependent signaling. Extensive 
investigations on QS signal interference mechanisms might broaden the scope of modern microbiological research.

\section{MECHANISM OF ACTION}

Plant nutrient management indicates the potentiality of effective microbials in increasing both macro- and micronutrients in the rhizosphere region (Rana et al., 2012) through change in total microbial community structure. The general mechanisms of plant nutrient management by microorganisms include associative nitrogen fixation, lowering of ethylene levels, production of siderophores and phytohormones, and production of growth regulators and VOCs, solubilization of nutrients, and promotion of mycorrhizal functioning. Figure 4 represents a flow chart showing important roles associated with the beneficial microbes such as PGPR, mycorhizal fungi, and mycorrhizal helper bacteria in agriculture. The PGP strains can promote plant growth and development either directly or indirectly (Ortiz-Castro et al., 2009). Direct stimulation includes biological nitrogen fixation, producing phytohormones such as auxins, gibberellins, cytokinins, and solubilizing minerals such as phosphorus $(\mathrm{P})$ and iron $(\mathrm{Fe})$, production of siderophores and enzymes, and induction of systemic resistance, while indirect stimulation is related to biocontrol strategies, including antibiotic production, chelation of available Fe in the plant rhizosphere, synthesis of extracellular enzymes to hydrolyze the fungal cell wall, and competition for niches within the rhizosphere (Zahir et al., 2004; van Loon, 2007; Bhattacharyya and Jha, 2012). Microbials under the genera such as Aspergillus, Bacillus, Beauveria, Pseudomonas, Streptomyces, and Trichoderma sp. are known for their efficiency in controlling plant diseases. Microorganisms are protective mainly because of their disease resistance capacity, antagonistic activity, production of elicitor

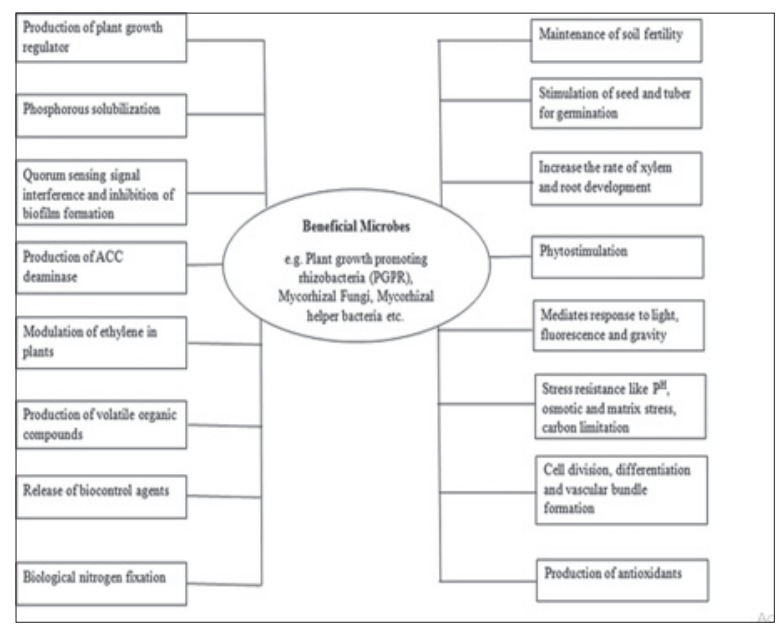

Figure 4: Mechanism of plant growth promotion by beneficial microflora molecules, environmental stress resistance activity, etc. (Higa and Parr, 1994).

Phytoextraction is considered as another microbial mechanism of crop protection (Sessitsch et al., 2013). Phytoextraction involves the use of trace element accumulating plants that concentrate the pollutants in their respective cells or tissues. After proper absorption of pollutants, it can be removed by harvesting plants. The phytoextraction process may be mobilized by soil amendments that potentially increase trace element availability in the soil. Role of plant-associated bacteria to enhance trace element availability in the rhizosphere is already established (Sessitsch et al., 2013). The enhanced rate of trace element uptake by beneficial microbials might be attributed to a microbial modification of the absorptive properties of the roots such as increasing the root length and surface area and numbers of root hairs or by increasing the plant availability of trace elements in the rhizosphere and the subsequent translocation to shoots via beneficial effects on plant growth, trace element complexation, and alleviation of phytotoxicity. Key processes in plant-bacteria interactions and colonization (Santhanam et al., 2014) by inoculated strains still need to be unraveled to allow fullscale application of bacteria assisted phytoremediation of trace element contaminated soils.

\section{Plant-microbe Interactions Due to Climate Change}

Climate change is the statistical change in the distribution of weather patterns (Compant et al., 2010) over an extensive period of time, ranging from decades to millions of years. Change in climate can alter the environmental conditions drastically as a result of which plant-microbe associations may be affected.

Microbial processes are often dependent on environmental factors (Compant et al., 2010; Kheyrodin and Ghazvinian, 2012) such as temperature, moisture, $\mathrm{CO}_{2}$ concentrations in atmosphere, enzyme activity, and nutrient availability, all of which are likely to be affected by climate change. Elevated $\mathrm{CO}_{2}$ had a positive influence on the abundance of arbuscular and ectomycorrhizal (ECM) fungi, whereas the effects on plant growth-promoting bacteria and endophytic fungi were more variable. The mycorrhizal fungus Pisolithus tinctorius that depends entirely on plant assimilates of Pinus silvestris L., are known to grown at a faster rate at increased $\mathrm{CO}_{2}$ concentrations (Ineichen et al., 1995). Mycelial biomass production by Hebeloma crustuliniforme in Pinus sylvestris (L.) Karst. seedlings were significantly greater under elevated $\mathrm{CO}_{2}$, up to a threefold increase in comparison with ambient $\mathrm{CO}_{2}$ (Fransson et al., 2005). 
This suggests the ability of the fungus to produce more mycelium as a consequence of increased $\mathrm{C}$ availability. However, the mycorrhizal hyphal growth is found to be reduced due to elevated $\mathrm{CO}_{2}$ concentrations. Elevated $\mathrm{CO}_{2}$ concentration is likely to increase the $\mathrm{C}$ (carbon) allocation to the plant roots and thereby significantly hampers the normal physiological and growth promoting activities of plant root associated microbes. The effects of increased temperature on beneficial plant-microbe associations are more variable and varied considerably with the study system and the temperature range investigated. Temperature and soil type may affect the performance of plant-beneficial bacteria (Egamberdiyeva and Hoflich, 2003) certain PGP strains are known to grow better at a high temperature than at a low temperature and could be of special interest for application in agriculture exposed to increased temperatures. Waldon et al. (1989) showed that rhizobia isolated from nodules of the desert woody legume Prosopis glandulosa grew better at $36^{\circ} \mathrm{C}$ than at $26^{\circ} \mathrm{C}$. Another investigation with endophyte Burkholderia phytofirmans strain PsJN demonstrated that a temperature increase from $10^{\circ} \mathrm{C}$ to $30^{\circ} \mathrm{C}$ reduced the colonization of the strain in tomato rhizosphere. Increase in temperature can significantly alter the structure of mycorrhizal hyphal network system that may be linked to faster $\mathrm{C}$ allocation. According to the International Panel on Climate Change (IPCC) report (2007), warming of the climate system is occurring at unprecedented rates and an increase in anthropogenic greenhouse gas concentration is responsible for most of this warming activity. Global surface temperatures are predicted to increase in between $1.8^{\circ} \mathrm{C}$ and $3.6^{\circ} \mathrm{C}$ by the year 2100 due to this climate change phenomenon. Drought stress, another consequence of global climate change, is known to reduce the formation of extra mycorrhizal mycelium in plant roots (Sharma et al., 2014). Further, a specific adaptation in colonization by some ECM species seems to occur, which may lead to community shifts under reduced soil water availability. Different PGPRs, ecto or endo-mycorrhizal taxa, however, respond differently to droughts in terms of their patterns of abundance. For instances, in mediterranean shrubs such as Pinus muricata and Pinus oaxacana drought significantly decreased the microbial colonization process (Compant et al., 2010). Drought is also known to bring the losses in photosynthates accumulating in the plants during photosynthesis. A positive response of drought stress on plant growth-promoting microorganisms is also recorded. In stress agriculture, the rhizobacterial inoculants can, thus, be used either as biofertilizer, plant strengthener, phytostimulator or biopesticide depending on their mode of action and efficiency (Sharma et al.,
2014). Microbial methanogenesis (Mesle et al., 2013) is responsible for both natural and human induced $\mathrm{CH}_{4}$ emissions since methanogenic archaea reduces carbon into $\mathrm{CH}_{4}$ in anaerobic, carbon-rich environments such as ruminant livestock, rice paddies, and wetlands. Methanotrophs are important regulators of $\mathrm{CH}_{4}$ fluxes in the atmosphere, but due to their slow growth rate and firm attachment to soil particles it is difficult to isolate. In the carbon cycle, methanogens convert $\mathrm{CO}_{2}$ to $\mathrm{CH}_{4}$ (a process called methanogenesis). Further, exploration of these methanotrophs could effectively help to reduce $\mathrm{CH}_{4}$ emissions.

\section{FUTURE PROSPECTS AND CHALLENGES}

Microbes and their diverse metabolic activities are of significant importance for the sustainability of life on our planet, including recycling of elements on which primary productivity depends on. Microorganisms are essential in degradation of environmental wastes and restoration of degraded ecosystems. Conservation of microbial diversity is essential (Colwell, 1997) in the maintenance of species diversity of higher organisms and management of strategies such as plant disease management and nutrient management. Climate change affects the plant-microbe associations (Classen et al., 2015) in many ways, although the effects are dependent on plant species, ecosystem type, soil type, or microbial genotype. Microbial communities with different mechanisms produce signals (Li and Tian, 2012) that may in the long term, either result in the establishment of altered communities or in the elicitation of different plant responses. As a result of altered community structures, beneficial microorganisms might have to compete with different microbial communities and therefore might show an altered colonization behavior.

Microbial application to enhance the fertility of soil and removing the soil contaminations through bioremediation technology is extensively used in developed countries such as UK and USA. In India, works has been initiated and subsequently developed in applying microorganisms for restoration of polluted soil through bioremediation. Applications of some potent fungal species such as Trichoderma formulations with strain mixtures perform better than individual strains for the management of pest and diseases of crop plants, in addition to plant growth promotion (Hadar et al., 1979; Kumar et al., 2014). Climate change induces adaptation processes in plants and microorganisms (Grover et al., 2011) and thereby changes the ability of plant-microbe associations. Particularly under elevated $\mathrm{CO}_{2}$ conditions, nutrients such as $\mathrm{N}$ might be limiting, leading to the need of 
enhanced fertilizer input in agriculture. Extensive research program also need to be developed to increase the capabilities of microbial remediation technologies to expand the exploitation of decontaminated soils and groundwater for healthy agricultural purposes as well for utilization of mankind with the changing climate scenario. Recently, The American Academy of Microbiology has extended enough knowledge for field trials of microbial bioremediation technology (Singh et al., 2014) to remediate natural environments from toxic substances and complex hydrocarbons. The ongoing microbial genomic study (Fraser et al., 2000; Fraser-Liggett, 2005) would deliver more robust knowledge and architecture for the bioremediation of metal contaminated waters and land. Exciting developments in the use of microorganisms for the recycling of metal waste, with the formation of novel biominerals with unique properties are still need to be exploited. Research should be concentrated to increase the shelf life of the microbial formulation by developing superior strains that might support to increase the shelf life of the organic formulations.

Microbial-bioinformatics (Bansal, 2005) is recent prospect. The growing number of microbial genome sequence provides a powerful tool for studying the biology of microorganisms. Genomic-based approaches can facilitate efficient and direct research strategies to elucidate mechanisms on bacterial pathogenicity toward agriculture development. As genomic information accrues, the challenge remains to construct a picture of the biology that accurately reflects how individual genes collaborate to create the complex world of microbial specialization. In this $21^{\text {st }}$ century, it is the challenge to study about the protein structure (proteomics) and gene structures (genomics) of the diverse microbial populations that are identified as the potent strains in agricultural system. Emergence of molecular biology would be helpful to develop novel gene-based bioindustries to preserve and equally take care of the rich biodiversity and diverse microbial world. Culture collection laboratories throughout the world are encouraged to create novel and better techniques for bioprospecting of novel microorganisms and to carry out molecular sequence analysis to establish the phylogenetic relationship among explored microbial taxa for in situ investigations and ex situ conservation of microbial genetic resources and to execute taxon-based research on population structure of natural microbial consortia. For farmers struggling to adapt to climate change with limited land and water resources, an increase in crop yield with climate-smart farming techniques can create novel opportunities that would further conserve water and soil fertility and sustainably to agriculture.

\section{CONCLUSION}

Due to excessive and injudicial use of chemical fertilizers, agriculture faces diverse challenges (Plimmer, 1984; Bhattacharyya et al., 2015). Synthetic fertilizers are known to destroy a large percentage of soil's naturally-occurring nutrients. Moreover, due to long-term application of chemicals in soil, there are also losses of native soil microflora. Soil, deprived of its microorganisms, undergoes a rapid decline in soil structure, and it gradually loses its ability to retain water, air and nutrients. Plants grown in such depleted soil are extremely susceptible to damage from diseases, insects, and drought. The utilization of effective and beneficial microbes is the only way to overcome such type of obstacles. Soil rich in beneficial/effective microorganisms, encourages the natural immune system of the plants, limits the population of phytopathogens, resists parasitic insects, and creates ideal situations for agriculture. Integrated pest and disease management strategies should, therefore, be adopted for the control of pest and pathogenic attack in agriculture. Integrated nutrient management strategy is important for the maintenance of soil fertility and plant nutrient supply at an optimum level to sustain the desired crop productivity. This is done through optimization of the benefits from all possible sources of plant nutrients in an integrated manner. Both the two processes are ecofriendly and cost effective that would serve as an asset of sustainable agricultural practice. Attempts should be generated to assess and predict the climate change that might influence the diversity, distribution and activity of soil microbes capable of contributing overall plant growth and development potential. Change in environmental conditions due to climate alterations is likely to induce changes in plant physiology and root exudation (Madhu and Hatfield, 2013; Sardans and Penuelas, 2012). The research is essential to improve the knowledge on native biodiversity and microbial community structure, under changing climate scenario. Finally, though the evidence gathered so far demonstrates that climate change is likely to have a significant impact on plant and microbial growth, the exact consequences of future climate change on plantmicrobe interaction are difficult to predict due to the complex interactions between various climate parameters (e.g., $\mathrm{CO}_{2}$, temperature) and soil physicochemical properties (soil nutrition, microbial diversity, heavy metal concentration), etc.

\section{ACKNOWLEDGMENTS}

The corresponding author is thankful to the Director, Tocklai Tea Research Institute (TTRI), Tea Research 
Association (TRA), Jorhat, Assam, India, for his encouragement in research activities. The corresponding author is also indebted to the Head of the Department as well faculty members for their copious encouragement during the course of investigation.

\section{REFERENCES}

Adhya TK, Kumar N, Reddy G, Podile AR, Bee H, Bindiya S. Microbial mobilization of soil phosphorus and sustainable P management in agricultural soils. Curr Sci 2015;108:1280-7.

Agarry OO, Akinyosoye FA, Adetuyi FC. Antagonistic property of microorganisms associated with cassava (Manihot esculenta Crantz) products. Afr J Biotechnol 2005;4:627-32.

Ahemad M, Khan MS. Alleviation of fungicide-induced phytotoxicity in green gram [Vigna radiata (L.) Wilczek] using fungicide-tolerant and plant growth promoting Pseudomonas strain. Saudi J Biol Sci 2012a;19:451-9.

Ahemad M, Khan MS. Comparative toxicity of selected insecticides to pea plants and growth promotion in response to insecticide-tolerant and plant growth promoting Rhizobium leguminosarum. Crop Prot 2010;29:325-9.

Ahemad M, Khan MS. Effect of tebuconazole-tolerant and plant growth promoting Rhizobium isolate MRP1 on peaRhizobium symbiosis. Sci Hortic 2011a;129:266-72.

Ahemad M, Khan MS. Productivity of green gram in tebuconazole-stressed soil, by using a tolerant and plant growth promoting Bradyrhizobium sp. MRM6 strain. Acta Physiol Plant 2012b;34:245-54.

Ahemad M, Khan MS. Pseudomonas aeruginosa strain PS1 enhances growth parameters of green gram [Vigna radiata (L.) Wilczek] in insecticide-stressed soils. J Pest Sci 2011b;84:123-31.

Ahemad M, Khan MS. Toxicity assessment of herbicides quizalafop-p-ethyl and clodinafop towards Rhizobium pea symbiosis. Bull Environ Contam Toxicol 2009;82:761-6.

Ahemad M, Kibret M. Mechanisms and applications of plant growth promoting rhizobacteria: Current perspective. J King Saud Univ Sci 2014;26:1-20.

Aislabie J, Deslippe JR. Soil microbes and their contribution to soil services. In: Dymond, JR, editor. Ecosystem Services in New Zealand - Conditions and Trends. Lincoln, New Zealand: Manaaki Whenua Press; 2013.

Alvindia DG, Natsuaki KT. Biocontrol activities of Bacillus amyloliquefaciens DGA 14 isolated from banana fruit surface against banana crown rot-causing pathogens. Crop Protect 2009;28:236-42.

Andreote FD, Gumiere T, Durrer A. Exploring interactions of plant microbiomes. Sci Agric (Piracicaba, Braz.) 2014;71:528-39.

Arora DK, Saikia R, Dwievdi R, Smith D. Current status, strategy and future prospects of microbial resource collections. Curr Sci 2005;89:488-95.

Badri DV, Vivanco JM. Regulation and function of root exudates. Plant Cell Environ 2009;32:666-81.

Bale JS, van Lenteren JC, Bigler F. Biological control and sustainable food production. Philos Trans R Soc Lond B Biol Sci 2008;363:761-76.

Bansal AK. Bioinformatics in microbial biotechnology - A mini review. Microbiol Cell Fact 2005;4:19.

Basak BB, Biswas DR. Influence of potassium solubilizing microorganism (Bacillus mucilaginosus) and waste mica on potassium uptake dynamics by sudan grass (Sorghum vulgare Pers.) grown under two Alfisols. Plant Soil 2009;317:235-55.

Bardgett RD, Freeman C, Ostle NJ. Microbial contributions to climate change through carbon cycle feedbacks. The ISME J 2008;2:805-14.

Begum MM, Sariah M, Abidin MA, Puteh AB, Rahman MA. Antagonistic potential of selected fungal and bacterial biocontrol agents against Colletotrichum truncatum of soybean seeds. Pertanica JTrop Agric Sci 2008;31:45-53.

Beneduzi A, Peres D, Vargas LK, Bodanese-Zanettini MH, Passaglia LM. Evaluation of genetic diversity and plant growth promoting activities of nitrogen-fixing Bacilli isolated from rice fields in South Brazil. Appl Soil Ecol 2008;39:311-20.

Berg G, Grube M, Schloter M, Smalla K. Unraveling the plant microbiome: Looking back and future perspectives. Front Microbiol 2014;5:148.

Bertsch PM, Thomas GW. Potassium status of temperate region soils. In: Munson, RD, editor. Potassium in Agriculture. Madison, WI: American Society of Agronomy, Crop Science Society of America, and Soil Science Society of America; 1985. p. 131-62.

Bhardwaj D, Ansari MW, Sahoo RK, Tuteja N. Biofertilizers function as key player in sustainable agriculture by improving soil fertility, plant tolerance and crop productivity. Microb Cell Fact 2014;13:66.

Bhattacharyya PN, Jha DK. Plant growth-promoting rhizobacteria (PGPR): Emergence in agriculture. World J Microbiol Biotechnol 2012;28:1327-50.

Bhattacharyya PN, Sarmah SR, Dutta P, Tanti AJ. Emergence in mapping microbial diversity in tea (Camellia sinensis (L.) O. Kuntze) soil of Assam, North-East India: A novel approach. Eur J Biotechnol Biosci 2015;3:20-5.

Bhattacharyya PN. Diversity of Microorganisms in the Surface and Subsurface Soil of the Jia Bharali River Catchment Area of Brahmaputra Plains. PhD Thesis. Guwahati: Gauhati University; 2012.

Burg SP. Ethylene in plant growth. Proc Nat Acad Sci USA 1973;70:591-7.

Chandler D, Davidson G, Grant WP, Greaves J, Tatchell GM. 
Microbial biopesticides for integrated crop management: An assessment of environmental and regulatory sustainability. Trends Food Sci Tech 2008;19:275-83.

Chen X, Schauder S, Potier N, Van Dorsselaer A, Pelczer I, Bassler BL, et al. Structural identification of a bacterial quorum-sensing signal containing boron. Nature 2002;415:545-9.

Choong-Min R, Farag MA, Chia-Hui H, Reddy MS, Kloepper JW, Pare PW. Bacterial volatiles induce systemic resistance in Arabidopsis. Plant Physiol 2004;134:1017-26.

Choudhary DK, Johri BN, Prakash A. Volatiles as priming agents that initiate plant growth and defence responses. Curr Sci 2008;94:595-604.

Classen AT, Sundqvist MK, Henning JA, Newman GS, Moore JA, Cregger MA, et al. Direct and indirect effects of climate change on soil microbial and soil microbial-plant interactions: What lies ahead? Ecosphere 2015;6:1-21.

Colwell RR. Microbial diversity: The importance of exploration and conservation. J Ind Microbiol Biotechnol 1997;18:302-7.

Compant S, van der Heijden MG, Sessitsch A. Climate change effects on beneficial plant-microorganism interactions. FEMS Microbiol Ecol 2010;73:197-214.

Contreras-Cornejo HA, Macías-Rodríguez L, Cortes-Penagos C, Lopez-Bucio J. Trichoderma virens, a plant beneficial fungus, enhances biomass production and promotes lateral root growth through an auxin-dependent mechanism in Arabidopsis. Plant Physiol 2009;149:1579-92.

Cronin D, Moenne-LoccozY, Fenton A, Dunne C, Dowling DN, O' Gara F. Ecological interaction of a biocontrol Pseudomonas fluorescens strain producing 2, 4-diacetylphloroglucinol with the soft rot potato pathogen Erwinia carotovora subsp. atroseptica. FEMS Microbiol Ecol 1997;23:95-106.

Davey ME, O'toole GA. Microbial biofilms: From ecology to molecular genetics. Microbiol Mol Biol Rev 2000;64:847-67.

Davidson EA, Janssens IA. Temperature sensitivity of soil carbon decomposition and feedbacks to climate change. Nature 2006;440:165-73.

Demoz BT, Korsten L. Bacillus subtilis attachment, colonization, and survival on avocado flowers and its mode of action on stem-end rot pathogens. Biol Control 2006;37:68-74.

Djonovic S, Pozo MJ, Dangott LJ, Howell CR, Kenerley CM. Sm1, a proteinaceous elicitor secreted by the biocontrol fungus Trichoderma virens induces plant defense responses and systemic resistance. Mol Plant Microbe Interact 2006;19:838-53.

Egamberdiyeva D, Hoflich G. Influence of growth promoting bacteria on the growth of wheat in different soils and temperatures. Soil Biol Biochem 2003;35:973-8.

Farmer EE. Surface to air signals. Nature 2001;411:854-6.
Farrar K, Bryant D, Cope-Selby N. Understanding and engineering beneficial plant-microbe interactions: Plant growth promotion in energy crops. Plant Biotechnol J 2014; 12:1193-206.

Ferreira JH, Matthee FN, Thomas AC. Biological control of Euthypa lata on grape vine by an antagonistic strain of Bacillus subtilis. Phytopathology 1991;81:283-7.

Fransson PM, Taylor AF, Finlay RD. Mycelial production, spread and root colonisation by ectomycorrhizal fungi Hebeloma crustuliniforme and Paxillus involutus under elevated atmospheric $\mathrm{CO}_{2}$. Mycorrhiza 2005;15:25-31.

Fraser CM, Eisen JA, Salzberg SL. Microbial genome sequencing. Nature 2000;406:799-803.

Fraser-Liggett CM. Insights on biology and evolution from microbial genome sequencing. Genome Res 2005; 15:1603-10.

Gill SS, Tuteja N. Reactive oxygen species and antioxidant machinery in abiotic stress tolerance in crop plants. Plant Physiol Biochem 2010;48:909-30.

Glick BR. Plant growth-promoting bacteria: mechanisms and applications. Scientifica 2012;2012:15.

Gornall J, Betts R, Burke E, Clark R, Camp J, Willett K, et al.Implications of climate change for agricultural productivity in the early twenty-first century. Philos Trans R Soc Lond B Biol Sci 2010;365:2973-89.

Gregory GG, Schreiber LR, Leben C. Microorganisms antagonistic for producing antibiotic inhibitory to Ceratocysits ulmi. Phytopathology 1986;74:804-5.

Grover M, Ali SZ, Sandhya V, Rasul A, Venkateswarlu B. Role of microorganisms in adaptation of agriculture crops to abiotic stresses. World J Microbiol Biotechnol 2011;27:1231-40.

Hadar Y, Chet I, Henis Y. Biological control of Rhizoctonia solani damping off with wheat bran culture of Trichoderma harzianum. Phytopathology 1979;69:64-8.

Hajieghrari B, Torabi-Giglou M, Mohammadi MR, Davari M. Biological potential of some Iranian Trichoderma isolates in the control of soil borne plant pathogenic fungi. Afr J Biotechnol 2008;7:967-72.

Han J, Sun L, Dong X, Cai Z, Sun X, Yang H, et al. Characterization of a novel plant growth-promoting bacteria strain Delftia tsuruhatensis HR4 both as a diazotroph and a potential biocontrol agent against various plant pathogens. Syst Appl Microbiol 2005;28:66-76.

Hasan MA. Investigation on the nitrogen fixing cyanobacteria (BGA) in rice fields of North-West region of Bangladesh. III. Filamentous (heterocystous). J Environ Sci Nat Resour 2013;6:253-9.

Higa T, Parr JF. Beneficial and Effective Microorganisms for a Sustainable Agriculture and Environment. Atami, Japan: International Nature Farming Research Center; 1994.

Higa T, Wididana GN. The concept and theories of effective 
microorganisms. In: Higa, T, Parr, JF, editors. Beneficial and Effective Microorganisms for a Sustainable Agriculture and Environment. Atami, Japan: International Nature Farming Research Centre; 1991.

Holden MT, Ram Chhabra S, de Nys R, Stead P, Bainton NJ, Hill PJ, et al. Quorum-sensing cross-talk: Isolation and chemical characterization of cyclic dipeptides from Pseudomonas aeruginosa and other Gram-negative bacteria. Mol Microbiol 1999;33:1254-66.

Hunter P. Natural solutions to climate change. Greenhouse gases, high-energy crops and the future of the world. EMBO Rep 2008;9:508-11.

Imtiaj A, Tae-Soo L. Antagonistic effect of three Trichoderma species on the Alternaria porri pathogen of onion blotch. World J Agric Sci 2008;4:13-7.

Ineichen K, Wiemken V, Wiemken A. Shoots, roots and ectomycorrhiza formation of pine seedlings at elevated atmospheric carbon dioxide. Plant Cell Environ 1995;18:703-7.

Jahanian A, Chaichi MR, Rezaei K, Rezayazdi K, Khavazi K. The effect of plant growth promoting rhizobacteria (PGPR) on germination and primary growth of artichoke (Cynara scolymus). Int J Agric Crop Sci 2012;4:923-9.

Jeffries P, Barea JM. Arbuscular mycorrhiza: A key component of sustainable plant-soil ecosystems. In: Hock B, editor. The Mycota: Fungal Associations. Vol. IX. Berlin, Heidelberg, New York: Springer; 2001.

Jeffries P. Biology and ecology of mycoparasitism. Can J Bot 1995;73:1284-90.

Kapoor R, Kumar A, Kumar A, Patil S, Kaur APaM. Indole acetic acid production by fluorescent Pseudomonas isolated from the rhizospheric soils of Malus and Pyrus. Recent Res Sci Technol 2012;4:6-9.

Khan A, Jilani G, Akhtar MS, Naqvi SM, Rasheed M. Phosphorus solubilizing bacteria: Occurrence, mechanisms and their role in crop production. J Agric Biol Sci 2009;1:48-58.

Kheyrodin H, Ghazvinian K. Effect of climate change on soil global microorganisms. J Biol Chem Res 2012;29:310-9.

Kloepper JW, Gutierrez-Estrada A, Mclnroy JA. Photoperiod regulates elicitation of growth promotion but not induced resistance by plant growth-promoting rhizobacteria. Can J Microbiol 2007;53:159-67.

Kumar A, Bisht BS, JoshiVD, DhewaT. Review on bioremediation of polluted environment: A management tool. Int J Environ Sci 2011;1:1079-93.

Kumar S, Thakur M, Rani A. Trichoderma: Mass production, formulation, quality control, delivery and its scope in commercialization in India for the management of plant diseases. Afr J Agric Res 2014;9:3838-52.

Lian B, Wang B, Pan M, Liu C, Teng HH. Microbial release of potassium from K-bearing minerals by Thermophilic fungus Aspergillus fumigatus. Geochim Cosmochim Acta 2008;72:87-98.

Liu D, Lian B, Dong H. Isolation of Paenibacillus sp. and assessment of its potential for enhancing mineral weathering. Geomicrobiology J 2012;29:413-21.

MaY, Rajkumar M, LuoY, Freitas H. Inoculation of endophytic bacteria on host and non-host plants-effects on plant growth and Ni uptake. J Hazard Mater 2011;95:230-7.

Madhu M, Hatfield JL. Dynamics of plant root growth under increased atmospheric carbon dioxide. Agron J 2013;105:657-69.

Mahadtanapuk S, Sanguansermsri M, Cutler WR, Sardsud V, Anuntalabhochai S. Control of anthracnose caused by Colletotrichum musae on Curcuma alismatifolia using antagonistic Bacillus spp. Am J Agric Biol Sci 2007;2:54-61.

Marasco R, Rolli E, Ettoumi B, Vigani G, Mapelli F, Borin S, et al. A drought resistance-promoting microbiome is selected by root system under desert farming. PLoS One 2012;7:e48479.

McClure NC, Ali-Reza A, Clare BG. Construction of a range of derivatives of the biological control strain Agrobacterium rhizogenes K84: A study of factors involved in biological control of crown gall disease. Appl Environ Microbiol 1998;64:3977-82.

Mejia LC, Rojas EI, Maynard Z, Bael SV, Arnold AE, Hebbar P, et al. Endophytic fungi as biocontrol agents of Theobroma cacao pathogens. Biol Control 2008;46:4-14.

Mesle M, Dromart G, Oger P. Microbial methanogenesis in subsurface oil and coal. Res Microbiol 2013;164:959-72.

Mia MA, Shamsuddin ZH, Wahab Z, Marziah M. Effect of plant growth promoting rhizobacterial (PGPR) inoculation on growth and nitrogen incorporation of tissue-cultured Musa plantlets under nitrogen-free hydroponics condition. Aust J Crop Sci 2010;4:85-90.

Miao B, Stewart BA, Zhang F. Long-term experiments for sustainable nutrient management in China. A review. Agron Sustain Dev 2011;31:397-414.

Miller MB, Bassler BL. Quorum sensing in bacteria. Annu Rev Microbiol 2001;55:165-99.

Mohammadi K. Phosphorus solubilizing bacteria: Occurrence, mechanisms and their role in crop production. Resour Environ 2012;2:80-5.

Mohseni M, Norouzi H, Hamedi J, Roohi A. Screening of antibacterial producing actinomycetes from sediments of the Caspian sea. Int J Mol Cell Med 2013;2:64-71.

Murali M, Amruthesh KN, Sudisha J, Niranjana SR, Shetty HS. Screening for plant growth promoting fungi and their ability for growth promotion and induction of resistance in pearl millet against downy mildew disease. J Phytology 2012;4:30-6.

Neeno-Eckwall EC, Schottel JL. Occurrence of antibiotic 
resistance in the biological control of potato scab disease. Biol Control 1999; 16:199-208.

Neill C, Gignoux J. Soil organic matter decomposition driven by microbial growth: A simple model for a complex network of interactions. Soil Biol Biochem 2006;38:803-11.

Nicholson WL, Munakata N, Horneck G, Melosh HJ, SetlowP. Resistance of Bacillus endospores to extreme terrestrial and extraterrestrial environments. Microbiol Mol Biol Rev 2000;64:548-72.

Nihorimbere V, Ongena M, Smargiassi M, Thonart P. Beneficial effect of the rhizosphere microbial community for plant growth and health. Biotechnol Agron Soc Environ 2011;15:327-37.

Niklaus PA, Alphei J, Kampichler C, Kandeler E, Korner C, Tscherko D, et al. Interactive effects of plant species diversity and elevated $\mathrm{CO}_{2}$ on soil biota and nutrient cycling. Ecology 2007;88:3153-63.

Ortiz-Castro R, Contreras-Cornejo HA, Macías-Rodríguez L, Lopez-Bucio J.The role of microbial signals in plant growth and development. Plant Signal Behav 2009;4:701-12.

Panhwar QA, Radziah O, Zaharah AR, Sariah M, Razi IM. Role of phosphate solubilizing bacteria on rock phosphate solubility and growth of aerobic rice. J Environ Biol 2011;32:607-12.

Penyalver R, Lopez MM. Co-colonization of the rhizosphere by pathogenic Agrobacterium strains and nonpathogenic strains K84 and K1026, used for crown gall biocontrol. Appl Environ Microbiol 1999;65:1936-40.

Perez-Montano F, Alías-Villegas C, Bellogin RA, del Cerro P, Espuny MR, Jimenez-Guerrero I, et al. Plant growth promotion in cereal and leguminous agricultural important plants: From microorganism capacities to crop production. Microbiol Res 2014;169:325-36.

Phukan I, Madhab M, Sarmah SR, Bordoloi M, Nair SC, Dutta P, et al. Exploitation of PGP microbes of tea for improvement of plant growth and pest suppression: A novel approach. Two Bud 2012;59:69-74.

Plimmer JR. Chemicals for agriculture. IAEA Bull 1984;26:13-6.

Prosser JI. Microorganisms cycling soil nutrients and their diversity. In:Van Elsas, JD, Jansson, JK, Trevors, JT, editors. Modern Soil Microbiology. New York, NY: CRC Press; 2007. p. 237-61.

Rahi P, Vyas P, Sharma S, Gulati A, Gulati A. Plant growth promoting potential of the fungus Discosia sp. FIHB 571 from tea rhizosphere tested on chickpea, maize and pea. Indian J Microbiol 2009;49:128-33.

Rahul K, Amrita K, Singh M. Trichoderma: A most powerful bio-control agent-a review. Trends Biosci 2014;7:4055-8.

Rajkumar M, Freitas H. Effects of inoculation of plant growth promoting bacteria on $\mathrm{Ni}$ uptake by Indian mustard. Bioresour Technol 2008;99:3491-8.
Rana A, Saharan B, Nain L, Prasanna R, Shivay YS. Enhancing micronutrient uptake and yield of wheat through bacterial PGPR consortia. Soil Sci Plant Nutr 2012;58:573-82.

Rhodes CJ. Mycoremediation (bioremediation with fungi) - growing mushrooms to clean the earth. Chem Spec Bioavailab 2014;26:196-8.

Roberts SC, Shuler ML. Large scale plant cell culture. Curr Opin Biotechnol 1997;8:154-9.

Rodriguez H, Fraga R. Phosphate solubilizing bacteria and their role in plant growth promotion. Biotechnol Adv 1999; 17:319-39.

Roossinck MJ. The good viruses: Viral mutualistic symbioses. Nat Rev Microbiol 2011;9:99-108.

Russo A, Carrozza GP, Vettori L, Felici C, Cinelli F, Toffanin A. In: Agbo EC, editor.z Plant Beneficial Microbes and their Application in Plant Biotechnology. Innovations in Biotechnology. INTECH Open Access Publisher; 2012. p. $57-72$.

Rutherford ST, Bassler BL. Bacterial quorum sensing: Its role in virulence and possibilities for its control. Cold Spring Harb Perspect Med 2012;2:a012427.

Saba H, Vibhash D, Manisha M, Prashant KS, Farhan H, Tauseef A. Trichoderma - A promising plant growth stimulator and biocontrol agent. Mycosphere 2012;3:524-31.

Salvioli A, Ghignone S, Novero M, Navazio L, Venice F, Bagnaresi $\mathrm{P}$, et al. Symbiosis with an endobacterium increases the fitness of a mycorrhizal fungus, raising its bioenergetic potential. The ISME J 2016;10:130-44.

Santhanam R, Groten K, Meldau DG, Baldwin IT. Analysis of plant-bacteria interactions in their native habitat: Bacterial communities associated with wild tobacco are independent of endogenous jasmonic acid levels and developmental stages. PLoS One 2014;9:e94710.

Sardans J, Penuelas J. The role of plants in the effects of global change on nutrient availability and stoichiometry in the plant-soil system. Plant Physiol 2012;160:1741-61.

Sarmah SR, Dutta P, Begum R, Tanti AJ, Phukan I, Debnath S, et al. Microbial bioagents for controlling diseases of tea. Proceeding International Symposium on Innovation in Tea Science and Sustainable Development in tea Industry. China Tea Sci Soc Unilever Hangzhou China; 2005. p. 767-76.

Saxena J, Basu P, Jaligam V, Chandra S. Phosphate solubilization by a few fungal strains belonging to the genera Aspergillus and Penicillium. Afr J Microbiol Res 2013;7:4862-9.

Scherr SJ, McNeely JA. Biodiversity conservation and agricultural sustainability: Towards a new paradigm of 'ecoagriculture' landscapes. Philos Trans R Soc Lond B Biol Sci 2008;363:477-94.

Sessitsch A, Kuffner M, Kidd P, Vangronsveld J, Wenzel WW, Fallmann $\mathrm{K}$, et al. The role of plant-associated bacteria in the mobilization and phytoextraction of trace elements in 
contaminated soils. Soil Biol Biochem 2013;60:182-94.

Sharma AK, Bhattacharyya PN, Rajkhowa DJ, Jha DK. Impact of global climate change on beneficial plant-microbe association. Ann Biol Res 2014;5:36-7.

Sharma SB, Sayyed RZ, Trivedi MH, Gobi TA. Phosphate solubilizing microbes: Sustainable approach for managing phosphorus deficiency in agricultural soils. Springer Plus 2013;2:587.

Sheng XF. Growth promotion and increased potassium uptake of cotton and rape by a potassium releasing strain of Bacillus edaphicus. Soil Biol Biochem 2005;37:1918-22.

Shridhar BS. Review: Nitrogen fixing microorganisms. Int J Microbiol Res 2012;3:46-52.

Singh LP, Gill SS, Tuteja N. Unraveling the role of fungal symbionts in plant abiotic stress tolerance. Plant Signal Behav 2011;6:175-91.

Singh R, Singh P, Sharma R. Microorganism as a tool of bioremediation technology for cleaning environment: A review. Proc Int Acad Ecol Environ Sci 2014;4:1-6.

Somers E, Vanderleyden J, Srinivasan M. Rhizosphere bacterial signalling: A love parade beneath our feet. Crit Rev Microbiol 2004;30:205-40.

Sood A, Sharma S, Kumar V, Thakur RL. Antagonism of dominant bacteria in tea rhizosphere of Indian Himalayan regions. J Appl Sci Environ Manage 2007;11:63-6.

Sparks DL, Huang PM. Physical chemistry of soil potassium. In: Munson RD, editor. Potassium in Agriculture. Madison, WI: American Society of Agronomy; 1985. p. 201-76.

Steeghs M, Bais HP, de Gouw J, Goldan P, Kuster W, Northway $M$, et al. Proton-transfer-reaction mass spectrometry as a new tool for real time analysis of rootsecreted volatile organic compounds in Arabidopsis. Plant Physiol 2004;135:47-58.

Thakur M, Sohal BS. Role of elicitors in inducing resistance in plants against pathogen infection: A review. ISRN Biochem 2013;2013:1-10.

Tolba IH, Soliman MA. Efficacy of native antagonistic bacterial isolates in biological control of crown gall disease in Egypt. Ann Agric Sci 2013;58:43-9.

Turner TR, James EK, Poole PS. The plant microbiome.
Genome Biol 2013;14:209.

Vacheron J, Desbrosses G, Bouffaud ML, Touraine B, MoenneLoccoz Y, Muller D, et al. Plant growth-promoting rhizobacteria and root system functioning. Front Plant Sci 2013;4:356.

van Loon LC. Plant responses to plant growth-promoting rhizobacteria. Eur J Plant Pathol 2007;119:243-54.

Verstraete W, Wittelbolle WL, Heylen K, Vanparys B, de Vos P, van deWieleT, et al. Microbial resource management: The road to go for environmental biotechnology. Eng Life Sci 2007;7:117-26.

Vessey JK. Plant growth promoting rhizobacteria as biofertilizers. Plant Soil 2003;255:571-86.

von Bodman SB, Bauer WD, Coplin DL. Quorum-sensing in plant-pathogenic bacteria. Annu Rev Phytopathol 2003;41:455-82.

Waldon HB, Jenkins MB, Virginia RA, Harding EE. Characteristics of woodland rhizobial populations from surface- and deep-soil environments of the Sonoran Desert. Appl Environ Microbiol 1989;55:3058-64.

Walpola BC, Min-Ho Y. Prospectus of phosphate solubilizing microorganisms and phosphorus availability in agricultural soils: A review. Afr J Microbiol Res 2012;6:6600-5.

Wang ET, Martinez-Romero E. Sesbania herbacea - Rhizobium huautlense nodulation in flooded soils and comparative characterization of $S$. herbacea - nodulating rhizobia in different environments. Microb Ecol 2000;40:25-32.

Yamada Y, Nihira T. Microbial hormones and microbial chemical ecology. In: Barton DH, Nakanishi K, editors. Comprehensive Natural Products Chemistry. Vol. 8. Amsterdam: Elsevier Sciences; 1998. p. 377-413.

Yang Y, Shah J, Klessig DF. Signal perception and transduction in plant defense responses. Genes Dev 1997;11:1621-39.

Zahir ZA, Muhammad A, Frankenberger WT. Plant growth promoting rhizobacteria: Applications and perspectives in agriculture. Adv Agron 2004;81:97-168.

Zivkovic S, Stojanovic S, Ivanovic Z, Gavrilovic V, Popovic T, Balaz J. Screening of antagonistic activity of microorganisms against Colletotrichum acutatum and Colletotrichum gloeosporioides. Arch Biol Sci Belgrade 2010;62:611-23. 